\title{
A Survey on Environment Monitoring using Sensor Networks
}

\author{
Kavan Vyas ${ }^{1}$, Subhasini Shukla ${ }^{2}$, Hanan Dsouza $^{3}$, Jaison Chacko ${ }^{4}$, Daniel D’Souza ${ }^{5}$, Vivek Narnaware ${ }^{6}$ \\ ${ }^{2,6}$ Assistant Professor, ${ }^{1,3,4,5}$ Student \\ 1, 3, 4, 5, 6 Department of Mechanical Engineering \\ ${ }^{2}$ Department of Electronics and Telecommunication \\ St. John College of Engineering and Management \\ Palghar, India \\ ${ }^{1}$ kavan2998@ gmail.com, ${ }^{2}$ subhasinis@ sjcem.edu.in, ${ }^{3}$ hanan30598@ gmail.com, ${ }^{4}$ jaison915@ gmail.com, \\ 5dandsouza1510@hotmail.com, ${ }^{6}$ vivekn@ @jcem.edu.in
}

\begin{abstract}
Environment monitoring is one of the most important application of Robotic Sensor Network (RSN) and Wireless Sensor Network (WSN). Monitoring of various factors is required for different kinds of environments. These networks have a capability of measuring different parameters such as temperature, humidity and air quality. They also process, transmit, analyze and upload the data over the internet for future use and study. It can automate the system be giving commands based on the data measured for any system to get actuated. Monitoring such parameters using sensor networks helps the humans to avoid entering hazardous areas and can help the farmers to measure required parameters on the field from a remote location. A study and comparison of applications of RSN and WSN in different environments is presented in this review paper which can help make the life of such people easy.
\end{abstract}

Keywords-Wireless Sensor Network (WSN), Robotic Sensor Network (RSN), Environment Monitoring.

\section{INTRODUCTION}

Environmental monitoring is a very wide field of study which includes different domains such as monitoring of fish in water bodies, indoor environment, agricultural environment, greenhouse monitoring, forest monitoring and any other environment which is either natural or artificial. Indoor monitoring includes the amount of cooling or heating required in the indoor office or building premises, the amount of heat that gets generated and the conditioning of the air inside the building.

There are frequent forest fires in some part of the world which tend to become huge and cause a lot of damage to the ecosystem of that area. Use of such networks will give a signal by sensing the conditions and huge fires can be prevented at the start before it turns into a catastrophe.

Habitat monitoring refers to the animals, birds and other species living in the forests or in an area. There are many endangered animals and birds. The population trends and movement of such species can be studied and suitable measures can be taken to prevent them from getting extinct.

In agriculture and farming, the use of sensor networks is increasing rapidly. In olden days, traditional farming was done fully by hand and by using cattle and by estimating the soil and environmental conditions. After the introduction of sensor networks, the environmental and soil conditions are now monitored with higher accuracy. This improves the productivity and also the quantity of the grown crop. Mechanization has made lives easier for the farmers. The use of fertilizers, better quality seeds, and better knowledge of crop rotation along with sensor networks have greatly increased the amount of yield produced.

There has been a lot of research in WSN for environment monitoring in the recent years. There are many different methods, processes, microcontrollers and sensors which have been used by different researches some of which include, Arduino, Raspberry pi, temperature sensors and humidity sensors among others. This paper gives readers an idea of the different areas of applications and how the various researchers have applied sensor networks in different environments.

\section{LITERATURE REVIEW}

There are various types of environment monitoring systems such as agriculture monitoring, habitat monitoring, indoor living monitoring, greenhouse monitoring, climate monitoring and forest monitoring. Each of which can be monitored by using different systems as per the requirement of that environment. The basic idea is to setup a set of sensors and sensor nodes along with data transmission, realtime data collection and monitoring of parameters [1].

There are various applications of wireless sensor networks from the field of military to environmental monitoring, it helps quick responses and also enables to plan a response quickly. It can also be used for inventory control in logistics [2].

Sensor networks are low cost, low power systems that can be used to sense the required parameters such as temperature, pressure, air quality and others. Internet of Things (IoT) forms a connection between everyday electrical objects with the internet as well as the people. The sensor node consists of a microcontroller, a transceiver, memory, a power source and sensors. In [3], Arduino and Raspberry Pi are used. Raspberry pi is a low cost, low power computer of the size similar to a credit card. Arduino mega is a microcontroller board with ATmega2560. XBee module working on ZigBee technology is a wireless transmission device that can transmit data over long distances. Two sensors are used in [3], which are MQ2 and MQ7 gas sensors. The MQ2 gas sensor is highly sensitive to LPG, Propane, Hydrogen as well as Methane or any other combustible gas. Sensitivity characteristics graph is shown in 


\section{ISSN NO: 2350-1146 I.F-5.11}

[3, Fig 5.1.2]. The test is conducted for $\mathrm{H}_{2}, \mathrm{LPG}, \mathrm{CH}_{4}$, Alcohol, Propane and air. Another graph is for the effect of temperature and humidity is shown in [3, Fig 5.1.3]. Similarly, the graphs for MQ7 gas sensor are shown in [3, Fig 5.2.2, Fig 5.2.3].

Making the sensor nodes robotic and giving them mobility can have many advantages as discussed in [4]. Such as, it can be deployed at one location, travel along the programmed path without the need of a human to intervene and it can send the results and data to the controller. Broken nodes can be repaired with the help of such mobile robots. Having the robots run on solar power can help it become independent of a battery.

Use of WSN in Precision Agriculture (PA) has been described in [5]. Using wireless sensor networks and robotic sensor networks which includes storing as well as transmission of data, is highly useful in accomplishing the goals of precision agriculture. An Intelligent Greenhouse Monitoring System (IGMS) has been developed in [5]. It can monitor environmental parameters such as temperature, humidity and soil moisture. The low cost due to the absence of wires and less power consumption of these technologies make it preferable for agriculture monitoring applications. A figure in [5, Fig. 1] shows the general WSN architecture. The architecture of several sensor nodes in PA is shown in [5, Fig. 2]. IGMS is specially designed system for greenhouses using open source technologies. The sensors used here are temperature and humidity, but it can also support sensors such as pH, NPK (Nitrogen, Phosphorous and Potassium) and salinity. When a threshold value is reached, the respective desired action is completed. A table [5, Table 1] shows the difference between amount of water and fertilizer consumed in scheduled and automatic irrigation.

Environmental monitoring is one of the main applications of WSN. A robotic sensor network is developed for monitoring of fish named carp in lakes. The fishes are caught and a transmitter is inserted in their skin before they are released back in the lake. This would help to study the fish behavior by tracking and tagging them. Where can they be found and how the temperatures affect their movement can be studied in this manner. The transmitters emit pulses in short intervals which is picked up by an antenna on the ground. It is also linked to GPS for finding the coordinates of the fish [6].

As per the study in [7], greenhouses currently have a large number of electronic measuring devices which results in intertwining cables. This increases the cost and investment of the greenhouse. The WSN is made using ZigBee Technology which is low cost, low power consumption, low complexity system and can communicate wirelessly over short distances. A flowchart shown in [7, Fig1.] describes the process of network address searching and mode of transmission. The network structure is as follows; the monitoring center is at the top following which the ZigBee master node in the middle and the sensor nodes at the bottom. The sensor module uses a temperature and humidity sensor and a $\mathrm{CO}_{2}$ sensor. A block diagram of the system with the microprocessor is shown in [7, Fig. 2]. The data of temperature, humidity and $\mathrm{CO} 2$ are sent to the coordinator at an interval of 30 seconds and battery voltage is sent every 60 seconds. A flowchart for user duty is shown in [7, Fig. 3].
WSNs are used for environmental monitoring in a coffee factory to keep note of gas emissions and waste water quality. Typically, measurements of such parameters are done manually at a certain interval or by using wired systems which are costly and not feasible. It is hazardous to manually measure parameters in chimneys and in sewer pipes. There is a high possibility that a harmful discharge if done will be detected much later if this method is used. A wireless system is safer and more reliable. A closed loop system has been developed which makes the environmental impact assessment [8]. The measurement of parameters is done for the sewage water and for the gas emissions which result from the manufacturing process. If the parameters measured are above the specified limits, a check on the manufacturing process is done.

Collection of sensor data and irrigation control for vegetative crops is done in this work. Wireless sensor networks are used for the transmission of sensor data and connecting a smart phone through an application [9]. Arduino is used as the microcontroller. Air temperature and humidity sensor DHT22 is used. The surface soil moisture is measured by checking the conductivity of the soil. For the wireless transmission of data ZigBee module is used. The irrigation is automatic and it can also be controlled using a smart phone application from a remote location over the internet.

The paper [10] discussed the application of sensor networks in manufacturing plants with one base station which is located at the center of the building. These sensors are distributed across various equipments, walls, ceilings and machines. They will be utilized to monitor parameters such as humidity, pressure, temperature, vibration, motion and sound. The manner in which the sensors would transmit data and how it would perform is described further. A set of test problems are made so that the system and the outputs can be tested and the proper working of the system can be evaluated.

Greenhouse automation and monitoring system is designed and implemented in [11]. A comparison between the current systems is shown in [11, Table. 1]. Most of those systems are not available in India or are costly to set-up. Using IoT in agriculture is beneficial for the farmers. Raspberry $\mathrm{Pi}$ is a computer high in performance and small in size. It supports WiFi and Bluetooth connectivity. DHT11 sensor measures the temperature and humidity. Capacitive soil moisture sensor measures the moisture content present in soil. A prototype has been depicted in [11, Fig. 8] where the sensors are wired to the Raspberry Pi. A block diagram describing the system overview is shown in [11, Fig. 1]. There is one central server which is the Raspberry Pi board. It is connected to the sensors and the internet. The system has been designed to operate in three modes which are; time based, sensor based and manual. The former two modes, perform the calculations and the system makes decisions based on the same. In the latter mode, user makes the decisions using a smart phone or a desktop application. The sensor data is collected and preprocessed for error and noise reduction. This data is then uploaded on the IoT cloud where data will be stored for future use and analysis. The results of temperature and humidity analytics are shown in [11, Fig. 9].

Monitoring of forest environment is done in [12]. A wireless sensor network along with ZigBee is used. The ZigBee system can find another link to maintain 


\section{ISSN NO: 2350-1146 I.F-5.11}

communication if the current link has problems. The system architecture consists of sensor nodes, a coordinator node and a connection with the internet and a control center. This network structure is shown in [12, Fig. 2]. The ZigBee sensor node is used which consists of a sensor module, processor module and a wireless communication module. The block diagram of the sensor node is shown in [12, Fig. 3]. The hardware structure is shown in [12, Fig. 4]. An RF transmitter is attached to the wireless transceiver module. This system has to transmit real-time data and network reliability needs to be maintained.

WSNs are used for forest environment monitoring in [13]. The paper presents the findings of a twenty day deployment at Purple Mountain area in China. The system architecture consists of sensor nodes which are distributed in dense patches. The nodes transmit data to a local transit network and this data is then uploaded over the internet which can be accessed by any user. The architecture is shown in [13, Fig. 1]. The sensor node is based on TMote Sky platform which integrates MSP430 microcontroller. The sensors used here are temperature, humidity and light intensity. The nodes measure and transmit both environmental parameters as well as information such as battery voltage. The nodes are deployed as shown in [13, Fig. 3]. The data collection performance graph is shown in [13, Fig. 4]. It compares the expected values with the measured values of one node. The data is for temperature is compared between two nodes at two different locations of measurement and the graph is shown in [13, Fig. 4]. More such nodes can be used and a larger area can be covered.

Indoor environment monitoring system (IEMS) using ZigBee WSN is developed in [14]. IEMS architecture consists of layers with sensors at the lowest level, the TinyOS operating system above it, the sensor middleware above it which contains the Global Sensor Network (GSN) and at the top is the application and service provider. This architecture is shown in [14, Fig. 1]. Motes are the processing units that take inputs from sensors, process it and then sends it. The system is programmed and deployed to collect data. The nodes communicate wirelessly and forward the sensor data over ZigBee to the sink node which sends data to the GSN. The system is deployed in a building with classrooms, seminar halls, library and laboratories. Sensors used are temperature, humidity and barometric pressure. Data acquisition is done using TinyOS. A web-based interface is provided for viewing the real time as well as the historical data. It can also generate corresponding graphs. The future work can consist of inclusion of mobile sensor networks.

Low cost sensor network is developed for indoor environment monitoring in [15]. The overall system architecture is shown in [15, Fig. 1]. The main components are temperature sensor, humidity sensor and XBee wireless transceivers. Arduino microcontroller is used to manage the data from all the sensors. The specification of the sensors along with the cost is given in [15, Table 1]. The sensors and components need to be configured correctly and programmed to function together with other hardware. Before the actual implementation, a test run was carried out to check if the system functions correctly and gives the desired results. The test is done in a test room shown in [15, Fig. 6]. The ground of all the sensors is connected together to solve the issue of same type of sensors showing different readings due to different grounds and multiple Arduino processors.
The work in [16] is about the application of WSN for monitoring and counting of birds. This counting is done by using sensors fitted with microphones which will record the bird songs. The recordings will be recognized to find which species it belongs to and the population density of the species will be determined. Recognizing the bird species is the most important task as well as the first step. Parameterization process is done which represents bird songs in form of coefficients which is sent to a database. Species recognition is done based on algorithms such as J48 and NBTree. Results obtained after using various algorithms is shown in [16, Fig. 1]. Classification process is done to specify if the sound belongs to a particular species of birds. Counting algorithm is then run to count the number or birds. The drawbacks include the possibility of under-counting the birds. The experimental results of this system are show in [16, Fig. 7-11].

The research in [17] relates to monitoring the movement of radio tagged bats between their nesting boxes. A transceiver by Chipcon Company is used for wireless data transmission. A comparison between their chips CC1020 CC2420 is shown in [17, Table 1]. Microcontroller used is Microchip PIC 18LF4620. Solar panels are used to power the outdoor setup of the system. The architecture is shown in [17, Fig. 2]. The bats have been implanted with small RFID tags to help monitor their movements. The temperature and humidity values are recorded every two hours.

This paper [18] presents a report on their environment monitoring system in a hospital environment in Bogota, Columbia. IoT approach is used for deployment of WSN. Areas such as storage rooms, labs and freezers are monitored. The system contains three blocks which is the node layer WSN, local management layer (PC) and the cloud-based layer. Temperature and humidity is sensed, processed and communicated to the local PC by using tree network topology. The system is described in [18, Fig. 1]. MTMCM5000-MSP module is used for the network connections whose specifications are listed in [18, Table 1.]. Ubidots platform is used here for collection of generated data. The network distribution is shown in [18, Fig. 6]. The results have been summarized in three categories namely, power consumption, reliability and impact and remarks. The error in the results obtained each month decreased as shown in [18, Fig. 9].

In [19], a proposal is made for an inclusion of mobile robots into WSN structure. It can also enable it to be flexible for gathering information as well as for transmitting it. The possible detection and surveillance of polluted areas is done. The three main working states of the robots are robot in discovering state, robot in reorientation mode and robot in surveillance mode. The state transitions are shown in [19, Fig. 2]. The robotic node prototype used is iRobot Create. It a provides WiFi connectivity to connect it with the PC (central node) for data transmission. In-lab experiment is conducted by modeling a dark colored floor as a polluted area. The reorientation and trajectory based on the IR sensors of the robot is described and shown. Another experiment is conducted when the pollution spot is not fixed and changes its position with time. A third experiment is performed using two robots and their cumulative performance and information exchange between them is studied. 


\section{ISSN NO: 2350-1146 I.F-5.11}

\section{COMPARISON OF EXISTING SYSTEMS}

The table shows the comparison of the existing systems and technologies. Various parameters for comparison have been chosen such as the area of application, the technology used, the microcontroller used, the sensors used, the communication channel, connection and the parameters measured in the system. The main area of application, sensor specifications, communication channel, the processor used and the parameters measured in the papers is mentioned in Table 1.

TABLE I. COMPARISON OF THE EXISTING SYSTEM

\begin{tabular}{|c|c|c|c|c|c|c|}
\hline $\begin{array}{l}\text { Refer- } \\
\text { ence }\end{array}$ & $\begin{array}{c}\text { Area of } \\
\text { Application }\end{array}$ & $\begin{array}{l}\text { Technology } \\
\text { Used }\end{array}$ & $\begin{array}{c}\text { Processor, } \\
\text { Microcontroller } \\
\text { and Development }\end{array}$ & Sensors Used & $\begin{array}{c}\text { Connection and } \\
\text { Communication } \\
\text { Channel }\end{array}$ & $\begin{array}{l}\text { Parameters } \\
\text { Measured }\end{array}$ \\
\hline [3] & $\begin{array}{l}\text { Environmental } \\
\text { monitoring for } \\
\text { gases }\end{array}$ & $\begin{array}{l}\text { ZigBee, WSN } \\
\text { and IoT }\end{array}$ & $\begin{array}{l}\text { Raspberry Pi, } \\
\text { Arduino Mega }\end{array}$ & $\begin{array}{l}\text { MQ2, MQ7 both of which } \\
\text { are gas sensors }\end{array}$ & $\begin{array}{c}\text { Wireless } \\
\text { communication using } \\
\text { XBee module }\end{array}$ & $\begin{array}{l}\text { Gases such as H2, } \\
\text { LPG, CH4, CO, } \\
\text { Alcohol, Propane } \\
\text { and air. }\end{array}$ \\
\hline [4] & $\begin{array}{c}\text { Mobilizing } \\
\text { sensor networks }\end{array}$ & $\begin{array}{c}\text { Robomote, } \\
\text { TinyOS Platform }\end{array}$ & Atmel 8535 & $\begin{array}{l}\text { IR proximity sensor, } \\
\text { Compass }\end{array}$ & $\begin{array}{l}\text { Byte to byte between } \\
\text { mote and robomote. }\end{array}$ & - \\
\hline [5] & $\begin{array}{l}\text { Precision } \\
\text { agriculture, } \\
\text { greenhouse } \\
\text { monitoring }\end{array}$ & IoT, WSN & $\begin{array}{l}\text { IGMS developed } \\
\text { here }\end{array}$ & - & $\begin{array}{l}\text { Wireless radio } \\
\text { frequency }\end{array}$ & $\begin{array}{c}\text { Temperature, } \\
\text { humidity and soil } \\
\text { moisture. }\end{array}$ \\
\hline [6] & $\begin{array}{l}\text { Monitoring } \\
\text { movement of } \\
\text { fish in lake } \\
\end{array}$ & $\begin{array}{l}\text { Robotic Sensor } \\
\text { Network (RSN) }\end{array}$ & $\begin{array}{c}\text { Eee PC, Robostix - } \\
\text { ATMEL } \\
\text { ATMega128 } \\
\end{array}$ & $\begin{array}{c}\text { Compass - Honeywell } \\
\text { HMC6352, GPS receiver - } \\
\text { Garmin 18x } \\
\end{array}$ & $\begin{array}{c}\text { Wireless - } \\
\text { Radio tags, directional } \\
\text { loop anteena } \\
\end{array}$ & $\begin{array}{c}\text { Finding exact } \\
\text { location of fish in } \\
\text { lake. } \\
\end{array}$ \\
\hline [7] & $\begin{array}{l}\text { Greenhouse } \\
\text { environment } \\
\text { monitoring }\end{array}$ & ZigBee, WSN, & $\begin{array}{c}\text { C8051F310 by } \\
\text { Cygnal with CIP-51 } \\
\text { core, CC2430 chip } \\
\text { for },\end{array}$ & $\begin{array}{l}\text { Specification not } \\
\text { mentioned }\end{array}$ & $\begin{array}{c}\text { Wireless } \\
\text { communication using } \\
\text { ZigBee }\end{array}$ & $\begin{array}{c}\text { Temperature, } \\
\text { humidity and } \\
\text { CO2. }\end{array}$ \\
\hline [8] & $\begin{array}{l}\text { Environment } \\
\text { monitoring in } \\
\text { Coffee Factory }\end{array}$ & $\begin{array}{l}\text { WSN, Cookie } \\
\text { platform }\end{array}$ & $\begin{array}{l}\text { Application } \\
\text { developed. }\end{array}$ & $\begin{array}{l}\text { Cookie nodes with; air } \\
\text { temperature and humidity } \\
\text { - SHT11, detection of } \\
\text { different gases - } \\
\text { electrochemical senor, } \\
\text { water temperature and pH } \\
\text { - cookie node. } \\
\end{array}$ & $\begin{array}{l}\text { ZigBee wireless } \\
\text { communication }\end{array}$ & $\begin{array}{c}\text { Waste water and } \\
\text { Chimney air } \\
\text { quality }\end{array}$ \\
\hline [9] & $\begin{array}{l}\text { Irrigation } \\
\text { control and } \\
\text { farm. }\end{array}$ & WSN, ZigBee & Arduino & $\begin{array}{l}\text { Temperature and Humidity } \\
\text { - DHT22, underground } \\
\text { water level and soil } \\
\text { moisture - CD4021BE IC } \\
\text { shift registers used. Sensor } \\
\text { and MCU developed. }\end{array}$ & $\begin{array}{c}\text { ZigBee (Xbee Series2) } \\
\text { wireless } \\
\text { comminication }\end{array}$ & $\begin{array}{l}\text { Temperature and } \\
\text { humidity and soil } \\
\text { moisture, } \\
\text { underground water } \\
\text { level }\end{array}$ \\
\hline [11] & $\begin{array}{c}\text { Greenhouse } \\
\text { automation and } \\
\text { monitoring }\end{array}$ & $\begin{array}{l}\text { IoT and end user } \\
\text { application }\end{array}$ & Raspberry Pi & $\begin{array}{c}\text { Temperature and humidity } \\
\text { - DHT11, Capacitive soil } \\
\text { moisture sensor. }\end{array}$ & $\begin{array}{l}\text { Sensors are wired to } \\
\text { the processor }\end{array}$ & $\begin{array}{l}\text { Air temperature, } \\
\text { humidity and soil } \\
\text { moisture }\end{array}$ \\
\hline [13] & $\begin{array}{c}\text { Forest } \\
\text { environment } \\
\text { monitoring }\end{array}$ & $\begin{array}{l}\text { TinyOS software, } \\
\text { marking of nodes } \\
\text { using GPS. }\end{array}$ & $\begin{array}{l}\text { MSP430 by Texas } \\
\text { Instruments and } \\
\text { Chipcon CC } 2420 \\
\text { radio. }\end{array}$ & - & $\begin{array}{c}\text { Wireless } \\
\text { communication based } \\
\text { on Tmote Sky } \\
\text { platform }\end{array}$ & $\begin{array}{c}\text { Temperature, } \\
\text { Humidity and TSR } \\
\text { light intensity. }\end{array}$ \\
\hline [14] & $\begin{array}{c}\text { Indoor } \\
\text { environment } \\
\text { monitoring }\end{array}$ & $\begin{array}{l}\text { WSN, ZigBee, } \\
\text { TinyOS, GSN. }\end{array}$ & IEMS developed. & $\begin{array}{l}\text { Crossbow made Iris motes } \\
\text { (motes sense, process and } \\
\text { transmit the data), MIB510 } \\
\text { and MIB520. }\end{array}$ & $\begin{array}{c}\text { Wireless } \\
\text { communication using } \\
\text { ZigBee }\end{array}$ & $\begin{array}{l}\text { Sensing light, } \\
\text { temperature, } \\
\text { humidity, noise } \\
\text { and barometric } \\
\text { pressure. }\end{array}$ \\
\hline$[15]$ & $\begin{array}{c}\text { Indoor } \\
\text { environment } \\
\text { monitoring }\end{array}$ & WSN, ZigBee & Arduino & $\begin{array}{c}\text { Digital temperature sensor } \\
\text { - DS18B20, analog } \\
\text { temperature sensor - } \\
\text { LM35, Humidity sensor - } \\
\text { DHT11 }\end{array}$ & $\begin{array}{l}\text { Wireless SD Shield } \\
\text { which allows easy } \\
\text { communication with } \\
\text { ZigBee. }\end{array}$ & $\begin{array}{l}\text { Temperature and } \\
\text { humidity. }\end{array}$ \\
\hline$[16]$ & $\begin{array}{c}\text { Habitat } \\
\text { Monitoring }\end{array}$ & $\begin{array}{c}\text { Parameterisation } \\
\text { process }\end{array}$ & $\begin{array}{c}\text { Different algorithms } \\
\text { such as J48 and } \\
\text { NBTree is used. }\end{array}$ & Microphone & - & $\begin{array}{l}\text { Bird singing } \\
\text { sounds are } \\
\text { recorded. }\end{array}$ \\
\hline [17] & $\begin{array}{c}\text { Habitat } \\
\text { Monitoring }\end{array}$ & $\begin{array}{l}\text { WSN, solar } \\
\text { panels for } \\
\text { powering the } \\
\text { system. }\end{array}$ & $\begin{array}{c}\text { Chipcon CC1020 } \\
\text { transciver, Microchip } \\
\text { PIC 18LF4620 } \\
\text { microcontroller }\end{array}$ & - & Wireless transmission & $\begin{array}{c}\text { Tracking of RFID } \\
\text { tagged bats, } \\
\text { temperature and } \\
\text { humidity in } \\
\text { nesting boxes. } \\
\end{array}$ \\
\hline [18] & $\begin{array}{c}\text { Hospital } \\
\text { Environment }\end{array}$ & $\begin{array}{c}\text { WSN, IoT, } \\
\text { Contiki operating }\end{array}$ & $\begin{array}{c}\text { MTM-CM5000-MSP } \\
\text { module, Local }\end{array}$ & - & $\begin{array}{c}\text { Ubidots - cloud-based } \\
\text { layer, wireless }\end{array}$ & $\begin{array}{l}\text { Temperature and } \\
\text { humidity }\end{array}$ \\
\hline
\end{tabular}




\begin{tabular}{|c|c|c|c|c|c|c|}
\hline & Monitoring & system & $\begin{array}{c}\text { management layer } \\
\text { software coded with } \\
\text { Python language }\end{array}$ & & transmission & \\
\hline [19] & $\begin{array}{c}\text { Polluted area } \\
\text { monitoring }\end{array}$ & $\begin{array}{l}\text { WSN, } \\
\text { autonomous } \\
\text { robots }\end{array}$ & $\begin{array}{l}\text { iRobotCreate, } \\
\text { Gumstix Verdex } \\
\text { Pro }^{\mathrm{TM}} \text { XL69 }\end{array}$ & IR Sensors & $\begin{array}{l}\text { WiFi connectivity, } \\
\text { wireless transmission }\end{array}$ & $\begin{array}{c}\text { Polluted regions } \\
\text { shown by black } \\
\text { coloured floor in a } \\
\text { lab setup. }\end{array}$ \\
\hline
\end{tabular}

\section{FUTURE SCOPE}

In future, with the help of intensive research in this field, many more systems can be developed for various applications. One area where it can be implemented in a large scale is in closed environment farming. As discussed in [20] controlled environment farming and agriculture is a vast field which includes growing different types of crops in a controlled and artificial environment. Such a system can be made fully automated from sowing the seeds to watering to even harvesting. Other areas of application of WSN can be in unmanned aerial vehicle-based deliveries of goods which are ordered online.

\section{CONCLUSION}

This paper gives an idea about all the various fields and areas of application under environment monitoring. WSN and RSN are very useful for environment monitoring. With the help of these networks, humans need not manually visit the location to check and measure the parameters. Instead, these networks can be setup once and the readings can be viewed and studied from a remote location such as home or an office. These systems will greatly reduce the exposure of humans to hazardous environments. It will help save lives of the laborers who do such dangerous tasks. Monitoring of parameters in chimneys, mines and sewer systems is a very hazardous job which can be done by these systems and the risk to the health of humans can be avoided. The basic requirement of such a system is a sensor node and a transmission module which is wireless or it can be robotic. To view these readings, either storing of data is required or simultaneous uploading of data over the internet is done so that it can be accessed, studied and analyzed anywhere.

\section{REFERENCES}

[1] Mohd Fauzi Othman and Khairunnisa Shazali, "Wireless sensor network applications: a study in environment monitoring system" Elsevier Procedia Engineering 41, 2012, pp. 1204 - 1210.

[2] Th. Arampatzis, J. Lygeros and S. Manesis, "A survey of wireless sensors and wireless sensor networks", Proceedings of the 2005 IEEE International Symposium on Mediterranean Conference on Control and Automation Intelligent Control, Limassol, Cyprus, June, 2005, pp. 719-714.

[3] Aarti Rao Jaladi, Karishma Khithani, Oankaja Pawar, Kiran Malvi and Gauri Sahoo, "Environmental monitoring using wireless sensor network based on IOT", International Research Journal of Engineering and Technology, vol: 04 Issue: 01, January 2017, pp. 1371-1378.

[4] Karthik Dantu, Mohammad Rahimi, Hardik Shah, Sandeep Babel, Amit Dhariwal and Gaurav S. Sukhatme, "Robomote: enabling mobility in sensor networks", IPSN 2005. Fourth International Symposium on Information Processing in Sensor Networks, 2005., Boise, ID, USA, 2005, pp. 404-409.

[5] Mohamed Rawidean Mohd Kassim, Ibrahim Mat and Ahmad Nizar Harun, "Wireless sensor network inpricision agriculture application". Inernational. Conference on Computer, Information and Telecommunication Systems (CITS), Jeju, South Korea, 2014, pp. 1-5.

[6] Deepak Bhadauria, Volkan Isler, Andrew Studenski and Pratap Tokekar, "A robotic sensor network for monitoring Carp in Minnesota lakes", 2010 IEEE International Conference on Robotics and Automation, Anchorage, Alaska, USA, May 2010, pp. 3837-3842.

[7] Ling-ling LI, Shi-feng YANG, Li-yan WANG and Xiang-ming GAO, "The greenhouse monitoring system based on wireless sensor network technology", 2011 IEEE International Conference in Cyber Technology in Automation, Control and Intelligent Syststems, Kunming, China, March 20-23, 2011, pp. 265-268.

[8] J. Valverde, V. Rosello, G.Mujica, J. Portilla, A. Uriarte, and T. Riesgo, "Wireless sensor network for environmental monitoring: application in coffee factory", Hindawi Publishing Corporation, Interntational Journal of Distributed Sensor Network, vol. 2012, article no. 638067.

[9] Nattapol Kaewmard and Saiyan Saiyod, "Sensor data collection and irrigation control on vegetable crop using smart phone and wireless sensor networks for smart farming", 2014 IEEE Conference on Wireless Sensors (ICWiSE), Subang, Malaysia, October, 2014, pp. 106-112.

[10] Sima Maleki, Rapinder Sawhney, Hamid Farvaresh and Mohammad Mehdi Sepehri, "Energy efficient hybrid wired-cum-wireless sensor network design”, Journal of Cleaner Production, vol. 85, April 2014, pp 408-418.

[11] Neel P. Shah and Priyang P. Bhatt, "Greenhouse automation and monitoring system design and implementaion", International Journal of Advanced Research in Computer Science, vol. 8, no. 9, NovemberDecember 2017, pp. 468-471.

[12] Huanqi Tao and Hang Zhang, "Forest monitoring application systems based on wireless sensor networks", 2009 Third International Sympoium on Intelligent Information Technology Application Workshops, Nanchang, China, November, 2009, pp. 227-230.

[13] Xiaochuan Jiang, Guoping Zhou, Yunfei Liu and Yixiong Wang, "Wireless sensor networks for forest environmental monitoring", The 2nd International Conference on Information Science and Engineering, Hanzhou, China, December, 2010, pp. 2514-2517.

[14] Suman Sarkar Bhunia, Sarbani Roy and Nandini Mukharjee, "IEMS: Indoor Environment Monitoring System using zigBee wireless Sensor Network", Proceeedings of the 2011 International Conference on Communication, Computing \& Security (ICCCS 2011), Odisha, India, February, 2011.

[15] Olukeke Bamodu, Liang Xia and Llewellyn Tang, "An indoor environnment monitoring system using low-cost sensor network", Elseiver, 4th International Conference on Power and Energy Systems Engineering, CPESE 2017, Berlin, Germany, Energy Procedia, vol. 141, Sepember 2017, pp. 660-666.

[16] Erick Stattner, Nicolas Vidot, Philippe Hunel and Martine Collard, "Wireless sensor network for habitat monitoring: A counting heuristic", 37th Annual IEEE Conference on Local Computer Networks - Workshops, Clearwater, FL, USA, October, 2012, pp. 753760.

[17] Graeme J. Pendock, Lisa Evans and Graeme Coulson, "Wireless sensor module for habitat monitoring", 2007 3rd International Conference on Intelligent Sensors, Sensor Networks and Information, Melbourne, Q1d., December, 2007, pp. 699-702.

[18] J. Cabra, D. Castro, J. Colorado, D. Mendez and L. Trujillo, "An IoT Approach for Wireless Sensor Networks Applied to e-Health Environmental Monitoring," 2017 IEEE International Conference on Internet of Things (iThings) and IEEE Green Computing and Communications (GreenCom) and IEEE Cyber, Physical and Social Computing (CPSCom) and IEEE Smart Data (SmartData), Exeter, Devon, UK, 2017, pp. 578-583.

[19] Sevil A. Ahmed, Vasil L. Popov, Andon V. Topalov, Nikola G. Shakev, "Environmental monitoring using a robotized wireless sensor network". AI \& Soc 33, 2018, pp. 207-214.

[20] Merle H. Jensen. (2002). "Controlled environment agriculture in deserts, tropics and temperate regions - A world review". Acta $\begin{array}{lll}\text { Horticulturae. } & 578 . & \text { doi: } 10.17660 / \text { ActaHortic.2002.578. }\end{array}$ 